\title{
Biosorption of an Anionic Dye, Eosin Yellow onto Pineapple Peels: Isotherm and Thermodynamic Study
}

\author{
Fabian Audu Ugbe ${ }^{1^{*}}$, Patrick Onuh Anebi ${ }^{2}$ and Victoria Abiola Ikudayisi ${ }^{3}$ \\ ${ }^{1}$ HQ 1 Division Supply and Transport, Nigerian Army, P.M.B. 2022, Kaduna, Nigeria \\ ${ }^{2}$ Department of Science Lab. Tech. Benue State Polytechnic, Ugbokolo, Nigeria \\ ${ }^{3}$ Department of Chemistry, University of Ilorin, Ilorin, Nigeria \\ * Corresponding author email: ugbefabianaudu@gmail.com
}

Received: 14 December 2017 / Revised: 18 January 2018 / Accepted: 18 January 2018 / Published: 4 February 2018

\begin{abstract}
Eosin Yellow (EY), an anionic dye (acid dye) was adsorbed using an agricultural waste, pineapple peels (PP) as bio-sorbent in order to investigate its suitability as an alternative adsorbent, and to give insight into the mechanisms of binding. The study includes: equilibrium isotherms and thermodynamics studies. The adsorption isotherm and thermodynamics experiments were conducted using batch equilibrium techniques. The adsorption data were fitted into Langmuir, Freundlich and Temkin isotherm models; as a result, the data fitted well into the Langmuir model from which the adsorption capacity, qe was obtained as $11.76 \mathrm{mg} / \mathrm{g}$. Experimental values of the thermodynamics parameters $(\Delta \mathrm{H}$, $\Delta \mathrm{S}$ and $\Delta \mathrm{G})$ and separation factor $\left(\mathrm{R}_{\mathrm{L}}\right)$ in combination suggested that the adsorption process was endothermic, feasible, spontaneous, and had high degree of freedom. Combined results of the isotherms and thermodynamic study suggested a physisorption-chemisorption mechanism for the adsorption process. Therefore, the results of the study could provide useful information to evaluate the raw pineapple peel powder as a cheap source of adsorbent for the removal of EY from waste water.
\end{abstract}

Keywords: Eosin Yellow, Pineapple peels, Adsorption, Isotherms, Thermodynamics

\section{Introduction}

Dyes are used extensively in various industries such as textiles, rubber, plastics, printing, leather, cosmetics, etc., and also in production of coloured products. These industries emit significant amounts of synthetic textile organic dye wastes amongst all industrial waste waters [1]. Eosin yellow is a pink water soluble acid dye (anionic dye) which also displays yellow-green fluorescence and with wavelength of maximum absorbance $\left(\lambda_{\max }\right)$ of $517 \mathrm{~nm}$ [2], [3]. High concentration of Eosin yellow can lead to severe health problems due to its carcinogenic properties. It can result to different effects on exposure to human skins such as allergic, dermatitis, skin irritation, and mutation among others [4]. It also inhibits protein-protein interaction and triggers geno-toxicity in man [5]. With water pollution becoming one of the most serious environmental problems, it is important for the water reserves to be treated effectively and wastewater treatment be carried out [6]. Different methods for removal of contaminants from wastewater have been extensively studied previously, such as chemical precipitation, electrochemical techniques, membrane filtration, ion exchange, photo-catalytic degradation using UV $\mathrm{TiO}_{2}$, biodegradation, sono-chemical degradation, adsorption technique etc. [6]. Adsorption has proved useful for the treatment of effluents. Adsorption is preferred over other 
processes due to possible regeneration, sludge free operation and recovery of the sorbent [4]. However, an efficient adsorption process is dependent upon a low-cost adsorbent with high adsorption capacity and, the need for an adsorbent to be biodegradable [7]. The effective treatment of the Eosin Y effluent is eco-friendly to aqueous environment [8]. The chemical structure of Eosin $\mathrm{Y}$ is presented in Figure 1 [2].<smiles>O=C(O[Na])c1ccccc1-c1c2cc(Br)c(=O)c(Br)c-2oc2c(Br)c(O[N+](=O)[O-])c(Br)cc12</smiles>

Figure 1: Chemical structure of Eosin Yellow

Only a few researchers have carried out investigations into the adsorption of Eosin yellow from aqueous systems using different adsorbents such as modified sawdust [8], conditioned chitosan hydrobeads [7], activated carbon [1], Teak Leaf Litter Powder [5] and EDTA modified chitosan [9].

Activated carbon is the most commonly used adsorbent, which is capable of adsorbing most dyes with high adsorption efficiency [10]. It is however, economically expensive and has a high cost of regeneration due to difficulty in desorption of the already adsorbed dye molecules [10], [11]. Various low-cost adsorbents that can compete favorably with Commercial activated carbon have been investigated as alternative adsorbents [11]. These low-cost adsorbents are majorly biological/agricultural wastes either in a raw or modified form such as orange peels, mango peels, saw-dust, rice husk, coconut coir, date palm seed, maize cob, sugarcane bagasses, egg shell, plantain peels, cassava peels etc. [2], [12], [13]. In the present study, pineapple peels (PP) is been investigated as an alternative adsorbent.
Pineapple (Ananas comosus) holds the third rank in the world tropical fruit production after banana and citrus. Pineapple is the edible member of the family Bromeliaceae [14]. Pineapple generates a lot of wastes such as the crown, peel and core which can be utilize as low-cost adsorbent for removal of contaminants from waste water. Few researches have previously been carried out to investigate the suitability of pineapple peels for the sorption of dyes such as safranin-O [11], 2, 6Dichlorophenol [15], methylene blue [16] etc. A review of characterization of pineapple peels sample showed that carboxyl, carbonyl and hydroxyl groups are prominent functional groups on its surface, an indication of good surface interaction with the binding materials [11], [15]. SEM analysis conducted by [11] revealed an irregular surface with a low and non-porous surface area, indicating that there is a good possibility for dye to be adsorbed onto the surface.

The objective of this study therefore, was to investigate the suitability of low-cost pineapple peels for the adsorption of eosin $\mathrm{Y}$ from waste water, and to provide insight into the mechanism of the adsorption process. The study includes: equilibrium isotherms and thermodynamics studies.

\section{Materials and Methods}

\subsection{Adsorbent and Adsorbate Preparation}

The pineapple peels were collected from pineapple traders along market road at Ugbokolo, Edumoga in Benue State, Nigeria. A sample of about $2 \mathrm{~kg}$ (estimated to be enough for the entire sorption process) was collected and air-dried in the laboratory at room temperature for five days. The sample was then pretreated according to the method reported by [12]. The sample was then passed through a $0.112 \mathrm{~mm}$ mesh sieve and used for subsequent experiment. The adsorbate, EY was purchased from Sigma Aldrich (Germany) and was used for the adsorption experiments without further purification. One-gram EY was weighed and dissolved in $1000 \mathrm{ml}$ of deionized water to make $1000 \mathrm{ppm}$, from which lower concentrations were prepared by serial dilution method. 
Ugbe et al., Int. Ann. Sci.; Vol. 4 Issue 1, pp: 14-19, 2018

\subsection{Adsorption Experiment}

A $0.1 \mathrm{~g}$ portion of the pineapple peels sample was weighed into different $100 \mathrm{ml}$ conical flasks and $15 \mathrm{ml}$ of working standard solution $(25,50,75$, 100, 150, 200, 250 and 300) ppm of the EY dye was added separately to the pineapple peel sample in the flask. Each solution was agitated on a flat orbital mechanical shaker for four (4) hours and then filtered. The filtrate was then analyzed using ultraviolet-visible spectrophotometer at $517 \mathrm{~nm}$ to determine the quantity of EY remaining in the solution [17]. The data generated from the experiment were then used to study the various isotherm models. The equilibrium concentration (concentration with the highest adsorption capacity), 250 ppm was selected for use in the subsequent experiment.

Further experiment was carried out using the equilibrium concentration at varying solution temperature (varied from 308 to $348 \mathrm{~K}$ ). The amount of the dye adsorbed by the adsorbents at equilibrium was determined using the mass balance equation (equation 1) [12]. The data generated from this experiment were then used to study the various thermodynamic parameters.

$$
\mathrm{q}_{\mathrm{e}}=\frac{\mathrm{v}\left(\mathrm{C}_{\mathrm{i}}-\mathrm{C}_{\mathrm{e}}\right)}{\mathrm{m}},
$$

Where $\mathrm{q}_{\mathrm{e}}$ is the quantity adsorbed by the adsorbent $(\mathrm{mg} / \mathrm{g}), \mathrm{V}$ is the volume of the adsorbate used (L), $\mathrm{m}$ is the mass of the adsorbent, $C_{i}$ and $C_{e}$ are the initial and final concentration of the adsorbate $(\mathrm{mg} / \mathrm{L})$ respectively.

In the present study, three models were being treated; Freundlich, Langmuir and Temkin isotherm models.

The Freundlich isotherm model assumes multilayer adsorption, with non-uniform distribution of adsorption heat and affinities over the heterogeneous surface [18].

$$
\ln \mathrm{q}_{\mathrm{e}}=\ln \mathrm{K}_{\mathrm{F}}+\frac{1}{\mathrm{n}} \ln \mathrm{C}_{\mathrm{e}},
$$

Where $\mathrm{q}_{\mathrm{e}}$ is the quantity adsorbed in $\mathrm{mg} / \mathrm{g}, \mathrm{C}_{\mathrm{e}}$ is the equilibrium concentration of the adsorbate in $\mathrm{mg} / \mathrm{L}, \mathrm{K}_{\mathrm{F}}$ is the Freundlich constant related to maximum adsorption capacity and $\mathrm{n}$ is the Freundlich constant related to surface heterogeneity (dimensionless).
On the other hand, Langmuir isotherm model assumes monolayer adsorption onto a surface containing a finite number of identical sites. The model assumes uniform energies of adsorption onto the surface and no transmigration of adsorbate in the plane of the surface [12], [19].

$$
\frac{\mathrm{C}_{\mathrm{e}}}{\mathrm{q}_{\mathrm{e}}}=\frac{1}{\mathrm{q}_{\mathrm{m}} \cdot \mathrm{K}_{\mathrm{L}}}+\frac{\mathrm{C}_{\mathrm{e}}}{\mathrm{q}_{\mathrm{m}}},
$$

Where $\mathrm{q}_{\mathrm{e}}$ is the concentration of dye retained by adsorbent in $\mathrm{mg} / \mathrm{g}$ or $\mathrm{mol} / \mathrm{g}, \mathrm{C}_{\mathrm{e}}$ is the concentration of dye in solution, $\mathrm{mg} / \mathrm{L}$ or $\mathrm{mol} / \mathrm{L}$, $K$ is a curve fitting parameter for equilibrium model and $\mathrm{q}_{\mathrm{m}}$ is the maximum adsorption capacity.

From the Langmuir equation the favorable nature of adsorption can be expressed in terms of dimensionless separation factor of equilibrium parameter, which is defined as:

$$
R_{L}=\frac{1}{1+K_{L} C_{O}}
$$

Where; $K_{L}$ is the Langmuir constant and $C_{o}$ is the highest initial concentration of the adsorbate in solution. The values of $R_{L}$ indicates the type of isotherm for an irreversible adsorption process $\left(R_{L}=0\right)$, favorable adsorption $\left(0<R_{L}<1\right)$, linear adsorption $\left(R_{L}=1\right)$ or unfavorable adsorption process $\left(R_{L}>1\right)$ [8], [10], [20].

Temkin isotherm model assumes that heat of adsorption (function of temperature) of all molecules in the layer would decrease linearly rather than logarithmic with coverage [21].

$$
\mathrm{q}_{\mathrm{e}}=\frac{\mathrm{RT}}{\mathrm{b}} \ln \mathrm{K}_{\mathrm{T}}+\frac{\mathrm{RT}}{\mathrm{b}} \ln \mathrm{C}_{\mathrm{e}},
$$

Where $K_{T}$ is the equilibrium binding constant ( $\mathrm{L} / \mathrm{mol}$ ) corresponding to the maximum binding energy, $\mathrm{b}$ is related to the adsorption heat, $\mathrm{R}$ is the universal gas constant $(8.314 \mathrm{~J} / \mathrm{K} / \mathrm{mol})$ and $\mathrm{T}$ is the temperature $(\mathrm{K})$.

In an effort to examine in greater details the effect of temperature on the sorption of EY by pineapple peels, thermodynamic parameters such as Gibb's free energy change $(\Delta G)$, enthalpy change $(\Delta H)$ and entropy change $(\Delta S)$ were estimated using equations 5, 6 and 7 [12], [22].

$$
\begin{aligned}
& \mathrm{K}_{\mathrm{c}}=\frac{\mathrm{q}_{\mathrm{e}}}{\mathrm{C}_{\mathrm{e}}}, \\
& \Delta \mathrm{G}=-\mathrm{RT} \ln \mathrm{K}_{\mathrm{c}}, \\
& \ln \mathrm{K}_{\mathrm{c}}=\frac{\Delta \mathrm{S}}{\mathrm{R}}-\frac{\Delta \mathrm{H}}{\mathrm{RT}},
\end{aligned}
$$


Where, $K_{C}$ is the concentration equilibrium constant, $\mathrm{q}_{\mathrm{e}}$ is the concentration of the dye in $\mathrm{mg} / \mathrm{g}$ on the surface of the adsorbent at equilibrium; $\mathrm{C}_{\mathrm{e}}$ is the concentration of the dye in $\mathrm{mg} / \mathrm{L}$ in the bulk solution at equilibrium, $\mathrm{R}$ is the universal gas constant equal to $8.314 \mathrm{Jmol}^{-1} \mathrm{~K}^{-1}$, T is the absolute temperature $(\mathrm{K}), \Delta \mathrm{S}$ is the entropy change $\left(\mathrm{JK}^{-1}\right), \Delta \mathrm{H}$ is the enthalpy change $\left(\mathrm{kJmol}^{-}\right.$ 1) and $\Delta G$ is the Gibb's free energy change $\left(\mathrm{kJmol}^{-1}\right)$. The values of $\Delta \mathrm{H}$ and $\Delta \mathrm{S}$ are determined from the slope and intercept of the Van't Hoff plot i.e. linear plot of $\ln K_{C}$ versus $1 / \mathrm{T}$ [18].

\section{Results}

\subsection{Adsorption Isotherm Study}

The various isotherm plots are presented in Figures 2-4 and the obtained isotherm parameters are shown in Table 1.

\subsection{Thermodynamic Study and the Effect of Temperature}

The result of effect of temperature on the sorption of EY on PP is shown in Figure 5 and that of the thermodynamic study are presented in Table 2 .

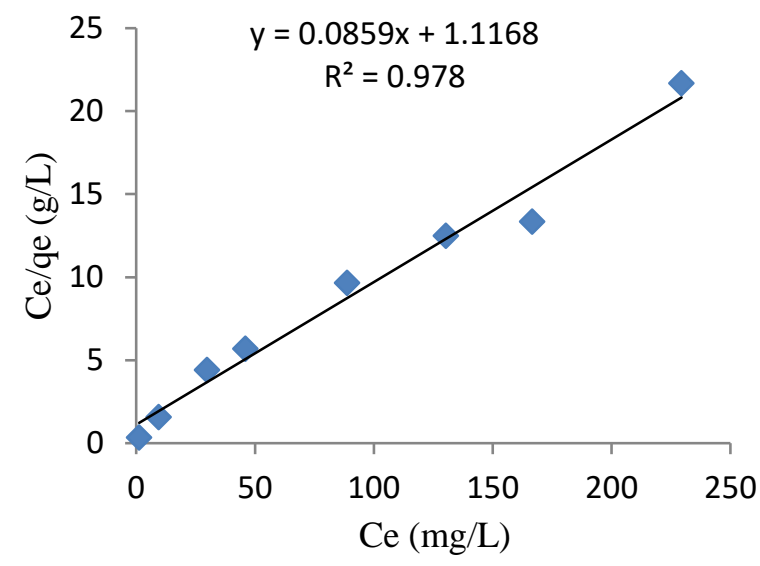

Figure 2: Langmuir isotherm plot for EY on PP

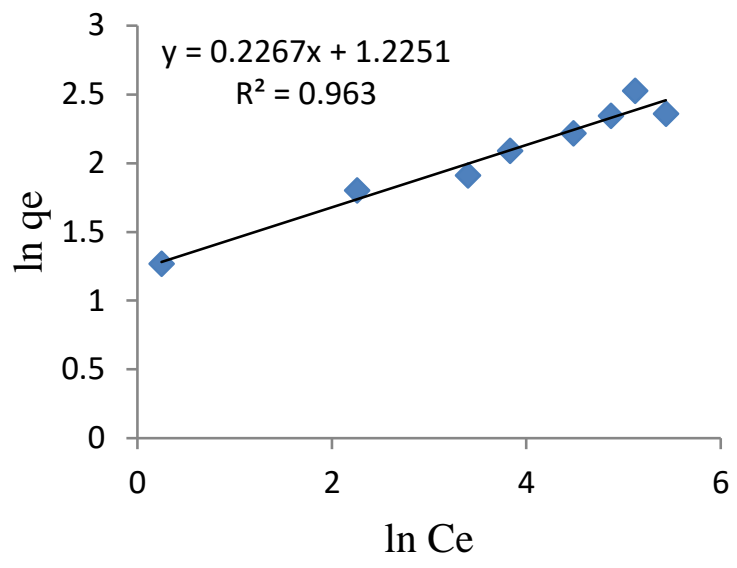

Figure 3: Freundlich isotherm plot for EY on PP

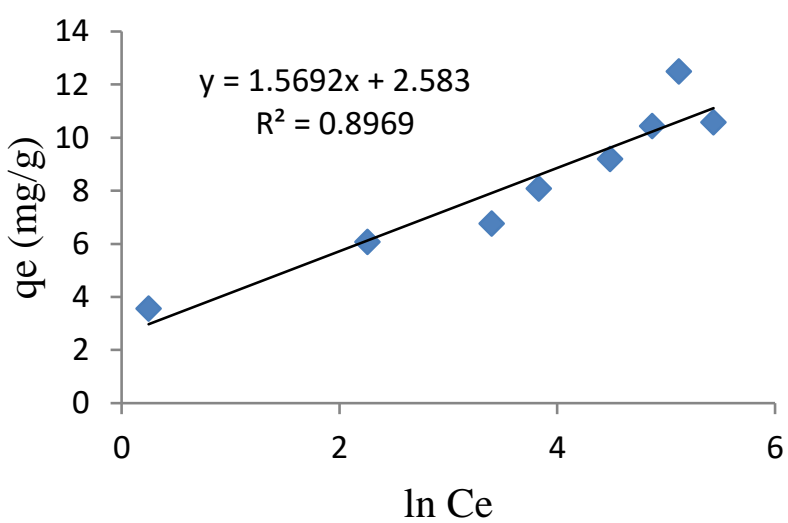

Figure 4: Temkin isotherm plot for EY on PP

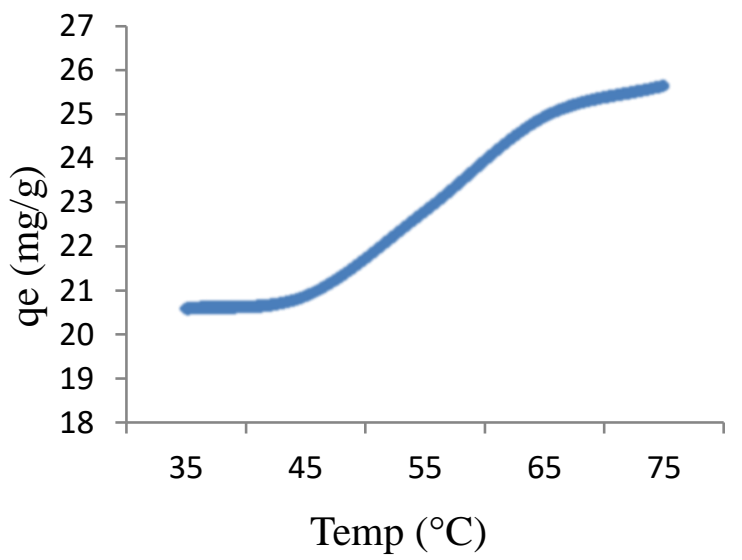

Figure 5: Effect of temperature plot for EY on PP

Table 1: The parameters obtained from Langmuir, Freundlich and Temkin isotherm models

\begin{tabular}{|c|c|c|c|c|c|c|c|c|c|c|}
\hline \multicolumn{10}{|c|}{ Isotherm Models } \\
\hline \multirow{2}{*}{$\mathrm{R}^{2}$} & $\mathrm{~K}_{\mathrm{L}}$ & $\mathrm{R}_{\mathrm{L}}$ & $\mathrm{q}_{\mathrm{m}}$ & $\mathrm{R}^{2}$ & $\mathrm{n}$ & $\mathrm{K}_{\mathrm{F}}$ & $1 / \mathrm{n}$ & $\mathrm{R}^{2}$ & $\mathrm{~A}$ & $\mathrm{~B}$ \\
& $(\mathrm{~L} / \mathrm{g})$ & $(\mathrm{L} / \mathrm{g})$ & $(\mathrm{mg} / \mathrm{g})$ & & & & & & \\
\hline & 0.094 & 0.04 & 11.76 & 0.963 & 4.424 & 3.404 & 0.226 & 0.896 & 5.18 & 1.57 \\
\hline
\end{tabular}


Table 2: Thermodynamics parameters obtained from the adsorption of $E Y$ on $P P$

\begin{tabular}{|c|c|c|c|c|}
\hline \multicolumn{2}{|c|}{} & \multicolumn{3}{|c|}{ Thermodynamics Parameters } \\
\hline $\begin{array}{l}\text { Temp } \\
(\mathrm{K})\end{array}$ & $\begin{array}{l}\mathrm{q}_{\mathrm{e}} \\
(\mathrm{mg} / \mathrm{g})\end{array}$ & $\begin{array}{l}\Delta \mathrm{G} \\
(\mathrm{kJ} / \mathrm{mol})\end{array}$ & $\begin{array}{c}\Delta \mathrm{S} \\
(\mathrm{kJ} / \mathrm{K})\end{array}$ & $\begin{array}{c}\Delta \mathrm{H} \\
(\mathrm{kJ} / \mathrm{mol})\end{array}$ \\
\hline 308 & 20.58 & -0.5002 & 0.047 & 14.3 \\
\hline 318 & 20.86 & -0.59714 & 0.047 & 14.3 \\
\hline 328 & 22.78 & -1.19173 & 0.047 & 14.3 \\
\hline 338 & 24.94 & -1.9256 & 0.047 & 14.3 \\
\hline 348 & 25.64 & -2.2312 & 0.047 & 14.3 \\
\hline
\end{tabular}

\section{Discussion}

\subsection{Adsorption Isotherm Study}

From Table 1, it was observed that the tested isotherm models showed good fitness into the experimental data with correlation coefficients $\left(\mathrm{R}^{2}\right)$ of $0.978,0.963$ and 0.896 for Langmuir, Freundlich and Temkin respectively. The best fit was therefore shown by the Langmuir model, an indication of monolayer coverage onto the surface of the pineapple peels, containing a finite number of identical sites with uniform energies of adsorption onto the surface. This suggests that the biosorption of EY onto PP was predominantly chemisorptions mechanism with physisorption also playing a role. This is in agreement with the results earlier reported by $[3$, and 10]. The obtained value of the separation factor $\left(R_{L}\right)$ was 0.04 (Table 1) which fall in the range $0<R_{L}<1$, an indication of the favorability of the adsorption process and high degree of irreversibility. Similar results were also reported by [3], [8], [10], [23]. Table 3 lists some maximum adsorption capacities of various dyes onto pineapple peels (PP).

Table 3: Maximum adsorption capacities of some dyes onto pineapple peels (PP)

\begin{tabular}{|l|l|l|l|}
\hline Adsorbent & Dye & $\begin{array}{r}\text { Q max } \\
(\mathrm{mg} / \mathrm{g})\end{array}$ & References \\
\hline $\mathrm{PP}$ & Eosin Y & 11.76 & Our Result \\
\hline $\mathrm{PP}$ & Mixed dyes & 16.01 & {$[23]$} \\
\hline $\mathrm{PP}$ & Safranin-O & 21.7 & {$[11]$} \\
\hline $\begin{array}{l}\text { PP/plantain } \\
\text { peels }\end{array}$ & $2,6-$ DCP & 76.92 & {$[15]$} \\
\hline
\end{tabular}

\subsection{Thermodynamic Study}

Figure 5 showed that the biosorption of EY onto PP is dependent on temperature i.e. the adsorption capacity increases gradually as the solution temperature was raised. It was also observed from Table 2 that the Gibb's free energy change decreases as the solution temperature increases which showed that the process becomes more feasible and spontaneous at increased temperature of the adsorption system. This is in agreement with results obtained by [10], [24]. Also, the magnitudes of the Gibb's free energy change fall between -20 and 0 $\mathrm{kJmol}^{-1}$, an indication of physisorption [12]. The positive value of the enthalpy change $(\Delta \mathrm{H})$ signifies an endothermic process (heat gain) which is evident in the increased adsorption capacity of the dye at higher temperatures. Similar result was reported by [12]. Also, the magnitude of $\Delta \mathrm{H}$ falls between 2.1-20.9 kJ mol-1, an indication of physical adsorption. The positive value of the entropy change $(\Delta S)$ showed great affinity of the pineapple peels towards the dye and that entropy serves as one of the major driving force in the adsorption. In addition, it showed increased randomness at the solid/solution interface with some structural changes in the Eosin $\mathrm{Y}$ and the PP. The adsorbed solvent molecules, which were displaced by the Eosin $\mathrm{Y}$, gain more translational entropy than is lost by the dye, thus allowing for the prevalence of randomness in the system [22].

\section{Conclusion}

The equilibrium adsorption data showed satisfactory correlation with the Langmuir isotherm more than the Freundlich and Temkin isotherms as determined by the higher correlation coefficient. The favourable adsorption of Eosin $\mathrm{Y}$ on PP was confirmed by the obtained values of the separation factor, $R_{L}$ and the Gibb's free energy change, $\Delta \mathrm{G}$. The removal of $\mathrm{EY}$ by $\mathrm{PP}$ is an endothermic and a spontaneous process. The maximum adsorption capacity was found to be $11.76 \mathrm{mg} / \mathrm{g}$ without any modification of the adsorbent. Combined results of isotherm and thermodynamic studies showed that the 
equilibrium removal of $\mathrm{EY}$ by the $\mathrm{PP}$ is that of a combined chemisorption and physisorption mechanism. The study shows that the raw pineapple peel powder can be considered as a cheap source of adsorbent for the removal of Eosin Yellow from waste water.

\section{How to Cite this Article:}

Ugbe et al "Biosorption of an Anionic Dye, Eosin Yellow onto Pineapple Peels: Isotherm and Thermodynamic Study", International Annals of Science, vol. 4, no. 1, pp. 14-19, Feb. 2018. doi: 10.21467/ias.4.1.14-19

\section{References}

[1] R. Kant, "Adsorption of Dye Eosin from an Aqueous Solution on two Different Samples of Activated Carbon by Static Batch Method," J. Water Resour. Prot., vol. 4, no. 2, pp. 93-98, Feb. 2012.

[2] Ugbe, F. Audu, Ikudayisi, and V. Abiola, "Renewable energy: Wastewater nexus," Edorium J. Waste Manag., vol. 2, pp. 5-11, Oct. 2017.

[3] S. Chatterjee, S. Chatterjee, B. P. Chatterjee, A. R. Das, and A. K. Guha, "Adsorption of a model anionic dye, eosin Y, from aqueous solution by chitosan hydrobeads," J. Colloid Interface Sci., vol. 288, no. 1, pp. 30-35, Aug. 2005.

[4] D. P. Samal, "Characterization of activated carbon and study of adsorption of methylene blue dye using activated carbon," May 2014.

[5] E. O. Oyelude, J. A. M. Awudza, and S. K. Twumasi, "Equilibrium, Kinetic and Thermodynamic Study of Removal of Eosin Yellow from Aqueous Solution Using Teak Leaf Litter Powder," Sci. Rep., vol. 7, no. 1, p. 12198 , Dec. 2017.

[6] Z. Cheng, A. L. K. Tan, Y. Tao, D. Shan, K. E. Ting, and X. J. Yin, "Synthesis and Characterization of Iron Oxide Nanoparticles and Applications in the Removal of Heavy Metals from Industrial Wastewater," Int. J. Photoenergy, vol. 2012, pp. 1-5, May 2012.

[7] J. Iqbal and M. L. Mirza, "Adsorption status of some transition metal ions on pretreated fish scales," $J$. Chem. Soc. Pakistan, vol. 27, no. 1, pp. 77-81, 2005.

[8] A. Reza And M. Z., "Removal of Eosin Y, An Anionic Dye, From Aqueous Solutions Using Conducting Electroactive Polymers," vol. 19, no. 7121. Iranian Polymer Journal (English), pp. 541-551, 01-Jan-2010.

[9] X.-Y. Huang, J.-P. Bin, H.-T. Bu, G.-B. Jiang, and M.H. Zeng, "Removal of anionic dye eosin $Y$ from aqueous solution using ethylenediamine modified chitosan," Carbohydr. Polym., vol. 84, no. 4, pp. 1350 1356, Apr. 2011.

[10] O. S. Bello, O. A. Olusegun, and V. O. Njoku, "Fly ash: An alternative to powdered activated carbon for the removal of eosin dye from aqueous solutions," Bull. Chem. Soc. Ethiop., vol. 27, no. 2, pp. 191-204, May 2013.

[11] M. M. A., A. Ibrahim, and A. Shitu, "Batch Removal of Hazardous Safranin-O in Wastewater Using Pineapple Peels as an Agricultural Waste Based Adsorbent," Int. J. Environ. Monit. Anal., vol. 2, no. 3, p. 128, May 2014.

[12] F. A. Ugbe, A. A. Pam, and A. V. Ikudayisi, "Thermodynamic Properties of Chromium (III) Ion Adsorption by Sweet Orange (Citrus sinensis) Peels," Am. J. Anal. Chem., vol. 5, no. 10, pp. 666-673, Jul. 2014.

[13] M. A. Funtua and F. A. Ugbe, "Adsorption of Heavy Metals from Aqueous Waste Water Using Unmodified and Ethylenediaminetetraacetic Acid (EDTA)
Modified Maize Cobs," Int. J. Curr. Res. Biosci. Plant Biol. Int. J. Curr. Res. Biosci. Plant Biol. Int. J. Curr. Res. Biosci. Plant Biol., vol. 2, no. 1, pp. 98-103, 2015.

[14] N. Selvanathan and N. S. Subki, "Dye Adsorbent by Pineapple Activated Carbon: $\mathrm{H}_{3} \mathrm{PO}_{4}$ and $\mathrm{NaOH}$ Activation," vol. 10, no. 20, 2015.

[15] S. E. Agarry and O. O. Ogunleye, Chemistry and Materials Research, vol. 7, no. 3. International Institute for Science, Technology and Education (IISTE), 2011.

[16] Yamuna M and K. M, "Pineapple peel waste activated carbon as an adsorbent for the effective removal of methylene blue dye from aqueous solution" [Online]. Available:

http://sphinxsai.com/2016/ch_vol9_no5/2/(544550)V9N5CT.pdf. [Accessed: 30-Jan-2018]

[17] M. Ibrahim and W. Jimoh, "Adsorption studies for the removal of $\mathrm{Cr}(\mathrm{VI})$ ion from aqueous solution," Bayero J. Pure Appl. Sci., vol. 1, no. 1, pp. 99-103, Aug. 2010.

[18] M. A. Al-Anber, "Removal of high-level Fe3+ from aqueous solution using natural inorganic materials: Bentonite (NB) and quartz (NQ)," Desalination, vol. 250, no. 3, pp. 885-891, Jan. 2010.

[19] I. Langmuir, "THE Constitution And Fundamental Properties Of Solids And Liquids. Part I. Solids.," J. Am. Chem. Soc., vol. 38, no. 11, pp. 2221-2295, Nov. 1916.

[20] Z. Shahryari, A. S. Goharrizi, and M. Azadi, International Journal of Water Resources and Environmental Engineering, vol. 2147483647, no. 2. Academic Journals, 2010.

[21] K. Y. Foo and B. H. Hameed, "Insights into the modeling of adsorption isotherm systems," Chem. Eng. J., vol. 156, no. 1, pp. 2-10, Jan. 2010.

[22] P. Saha and S. Chowdhury, "Insight Into Adsorption Thermodynamics," in Thermodynamics, InTech, 2011 [Online]. Available: http://www.intechopen.com/books/thermodynamics/in sight-into-adsorption-thermodynamics. [Accessed: 30Jan-2018]

[23] K. Singh and T. V. N. Padmesh, "Biosorption of Dyes onto Mango Seed and Pineapple Peel" [Online]. Available:

http://www.taylors.edu.my/EURECA/2014/downloads 156.pdf. [Accessed: 30-Jan-2018]

[24] H. K. Boparai, M. Joseph, and D. M. O'Carroll, "Kinetics and thermodynamics of cadmium ion removal by adsorption onto nano zerovalent iron particles," J. Hazard. Mater., vol. 186, no. 1, pp. 458465, Feb. 2011.

Publish your research article in AIJR journals-

$\checkmark$ Online Submission and Tracking

$\checkmark$ Peer-Reviewed

$\checkmark$ Rapid decision

$\checkmark \quad$ Immediate Publication after acceptance

$\checkmark \quad$ Articles freely available online

$\checkmark \quad$ Retain full copyright of your article.

Submit your article at journals.aijr.in

Publish your books with AIJR publisher-

$\checkmark$ Publish with ISBN and DOI.

$\checkmark$ Publish Thesis/Dissertation as Monograph.

$\checkmark$ Publish Book Monograph.

$\checkmark$ Publish Edited Volume/ Book.

$\checkmark$ Publish Conference Proceedings

$\checkmark \quad$ Retain full copyright of your books.

Submit your manuscript at books.aijr.org 